\title{
Public Communication Strategy of Pangandaran Regency Government Public Relations in Digital Era
}

\author{
Aat Ruchiat Nugraha ${ }^{1}$, Evi Novianti ${ }^{2}$, Lukiati Komala Erdinaya ${ }^{3}$, Kokom Komariah ${ }^{4}$ \\ \{ruchiat@unpad.ac.id ${ }^{1}$ \} \\ Universitas Padjadjaran, Indonesia ${ }^{1,2,3,4}$
}

\begin{abstract}
Public communication is a communication activity related to the delivery of information to stakeholders in order to get public support. To obtain the image of institutions in the digital era, the Pangandaran Regency Government uses and utilizes social media Instagram as a medium of interactive communication and public information. The purpose of this research is to explore and explain the use of Instagram used by the Public Relations of the Pangandaran Regency Government to promote sustainable development programs. This research uses a qualitative method approach with descriptive study through data collection techniques of interviews, observations, and documentation of social media activities of the Public Relations of Pangandaran Regency in the period between January-August 2019. The results of the research show that Instagram as a communication and information media of the Pangandaran Regency Government public relations is considered to be effective in conveying development information and government policy in the form of text, photographs, and audio-visuals attracting the attention of the public to participate.
\end{abstract}

Keywords: Public Communication, Social Media, Digital Era, Government Public Relations, Instagram.

\section{Introduction}

Information war and exposure in the digital era have reached the shores of Indonesia. Nowadays, people always receive information both offline and online with various communication strategies implemented by a particular organization delivering the organization's goals. As information delivery needed by the community, organizations, and individuals becomes more practical and straightforward, people now prefer the delivery of information through online media. As supported by a statement from Ayutiani, Primadani, \& Putri [1] which states that currently, communication is getting easier because technology facilitated the public with communication and a mean to get information quickly and instantly. One online media which is an alternative to receiving information that contains fewer hoaxes and hatred content is Instagram. Instagram is a photo-sharing service application that allows users to take pictures and provide filters and disseminate them on social media such as Facebook, Twitter, and others [2].

Information about public services is often the one which has been eagerly awaited by the public in getting fast and appropriate services from the government. Public information services carried out by the government are not only directly related to aspects of community needs but also related to government activities in the context of generating dialogical and interactive government communication. Government communication has the essence to guarantee the 
running of government functions in the interests of the community in achieving happiness in people's lives. Government activities represented by regional leaders in communicating through social media are usually related to the inauguration information of government activity, review of infrastructure development, policy explanations, and several activities related to social service socialization. It needs to be done to maintain harmony between the government and stakeholders towards good governance.

The ease of getting information by using Internet access supported by the existence of several social media chat applications has changed the pattern of communication Panuju \& Rahman [3], it is also affecting government agencies that convey information to the public. Despite its popularization, the term 'Information Society' is rather ill defined. For some scholars, it represents only an ideology, rather than a concept deriving from the findings of empirical observation of contemporary capitalism. In contrast to Castells's (1996) formulation of 'network society', Garnham (2000) rejects the statement that the social or economic organization of contemporary society is 'transformed' into an 'Information Society'. He asserts that the term, 'rather than serving to enhance our understanding often world in which we live, is used to elicit uncritical assent to whatever dubious proposition is being put forward beneath its protective umbrella'. Garnham seems to be arguing that the lack of any empirical data to point to 'the real-world phenomena' that can 'prove' the existence of an Information Society is stronger as evidence of the ideology of IS than its validity in describing a particular societal transformation. Webster too in Theories often Information Society (2002) discusses at some length the problems with identifying the exact meaning and location of the term in real life, in ways that can be observed not necessarily exclusively quantitatively. Therefore, although the 'measuring' of such a 'society' might be desirable in offering a picture of the trends and directions in employment, production, trade and distribution, it is not the only way to define the standards that will prove or disprove the new society. Webster generally maps the criteria applied by theorists to determine the emergence of IS in technological, cultural, economic, spatial and occupational categories. According to this taxonomy of 'criteria', the advent of the information or knowledge society tends to be identified with technological innovation and in particular the use of computer mediated communication systems in the same way that previous eras have been characterized as transformed by their own technological [4]. The transformation should be in motion as the growing spirit of openness in the community has been affected by the sophisticated communication and information system in which the community could easily access various problems, particularly aspects of government in managing and generating welfare towards its people. In order to have information and communication related to government aspects can be assessed by the public effectively, it requires an appropriate communication media in conveying the information coming from the government. One of the activities of regional leaders related to the delivery of information and communication is carried out by the Pangandaran Regency Government through the Regional Secretariat Public Relations who use and utilize Instagram account of @ humaspnd. Instagram becomes a means of socialization and evaluation of development programs that are being carried out by the government, which enables responses by the community. In which, government communication style, by using the influence of social media, especially Instagram, delivers effects to its users the same as the communication style found in the people who devoted themselves through Instagram [5].

The response from the community towards the Instagram post of @humaspnd indicates that the Pangandaran Regency Government has a significant awareness in managing public information need where Instagram as a social media is a suitable choice in the digital age. Gumilar [6] supported this notion by stating that in the development of social media, Instagram 
is not only used for personal needs but has an expanded use for other aspects, one of which is the aspect of public information disclosure, especially related to socialization activities. One of the socialization activities is the activities of regional leaders. Through the delivery of information on Instagram, at least the objectives of government communication can be achieved while the forming of information and communication should be able to create a positive image in the hearts of the public enabling the public to make decisions. Afkarina [7] regarding the assessment of the activities of regional leaders.

Instagram, as a social networking media, is quite effective in conveying the activities and programs of the Pangandaran Regency Government as a new regency, it even enables them to reach not only the public in Pangandaran but also the world. The phenomenon leads to the research focusing on explaining and determining the activities of Instagram communication media content created by the Regional Secretariat of the Pangandaran Regency Government.

\section{Research Methods}

Researches focusing on the use of information and communication technology through Instagram in a profit or non-profit organization has been occurring a lot lately. In the meantime, research on public communication strategies in the digital era is vital as an effort to support the socialization of the development policy of the Pangandaran Regency Government. This study uses a descriptive qualitative method to examine public communication strategies in the digital era in government institutions through the use of the Instagram social media platform in embracing the era of society 4.0. The data obtained in this study collected through interviews, observations, and documentation studies. The interview is conducted with public relations staff who also acts as the administrator of the @ humaspnd Instagram account. Observation and documentation study are carried out by collecting data relating to social media activities on Instagram@humaspnd during the period of January-August 2019. The literature review is carried out by examining and reviewing the literature relating to social media activities on Instagram contained in reference books and scientific journals.

After the data collection, the data is then categorized and constructed based on the messages obtained, and then followed by the mapping of public communication strategy in the digital by Pangandaran Regency Government. The data analysis technique uses Miles and Huberman's theory, which consists of several stages, namely, data reduction, data display, and data conclusions based on the researchers' interpretation. The validity of the research data uses methods of triangulation, accuracy, and extended observation.

\section{Results and Discussion}

As a new autonomous region (DOB), the Pangandaran Regency is the youngest area in the province of West Java; the need to communicate using a variety of resources, including information in online media occurs as it is needed to communicate all the development progress in the regency. The official online media utilized as information and communication media for the Pangandarana Regency Government are the use of Pangandaran Regency Public Relations accounts on Facebook, Instagram (@humaspnd), and the Pangandaran Public Relations Youtube. The three online media have different characteristics depending on the target public. On the Facebook platform, the target of the public to be achieved is the wider community, the 
Instagram account is focusing on more on people who prefer the aspect of tourism, and YouTube is focusing on a particular public who wants to know detailed information about a particular object.

The @ humaspnd account is an official Instagram account managed by public relations of the regional secretariat of the Pangandaran Regency, this account provides and conveys information related to the activities of regional leaders supporting Pangandaran tourism information. Based on search results until August 17, 2019, it shows that the Instagram account @ humaspnd managed to get 2,440 followers with 857 posts. The followers of this account are from the various public who are interested in information about Pangandaran. This government agency 's account has a low category of contents of the information. The potential outcome from this account could be invaluable as data suggest that Indonesia is one of the countries with the highest number of Instagram users, with 89 percent being Instagrammers aged 18-34 who access IG (Instagram) at least once a week. Instagrammers are mostly young, educated, and wellestablished [8]. So, when referring to the data above, the Instagram account @humaspnd should necessarily increase the number of informational posts in the form of photos and videos covering the regional leader's activities in a more millennial style that the public prefers.

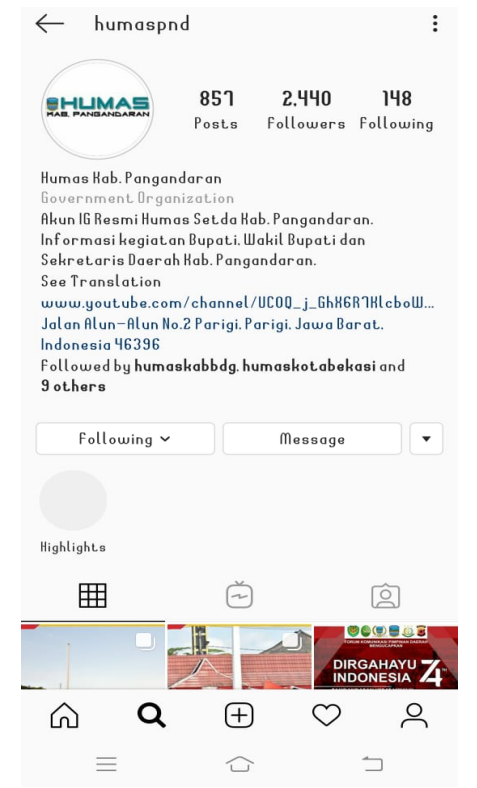

Fig. 1. Instagram page of @humaspnd (Instagram, 2019).

From figure 1. it can be seen that since December 2015, the @ humaspnd account has posted photos of the activities of the Pangandaran Regency leadership starting in the era of Pangandaran Regent H. Daud Achmad until the election of the definitive Regent of Pangandaran in the 2016-2021 period, namely H. Jeje Wiradinata and H. Adang Hadari, with a low number of engagements of comments and likes. This data shows the limited capability of the manager of the @humaspnd Instagram account in conveying information related to the activities carried out by the regional leaders. In addition, according to Nasrullah [9] who suggest that communication on the internet interaction occurs based on the visual presentation alone, which can provide a particular meaning to those involved. So, managing a communication activity via social media is not as simple as the Instagram motto, which is 'instant capture.' However, there 
is a set of circular elements that would be able to influence the success of an institution in managing social media that can attract public attention [10].

The@humaspnd account of the Pangandaran Regency Government invites all people in Pangandaran to jointly establish Pangandaran Regency as a world-class tourist destination per the objectives of the government. Regional leaders must continually communicate achievement of this objective, by utilizing various momentum that needs to be communicated to the broader community, specifically related to the socialization of policy programs and infrastructure development for community services. On Instagram, Public Relations of the Pangandaran Regency conveys various governance information with an exciting presentation in the form of pictures and videos. Some information presented in the @ humaspnd account categorized into several categories including a forum for the activities of the regent, deputy regent, and regional secretary in carrying out formal and informal duties in serving the needs of the Pangandaran community as part of government's role in implementing public service. Public service defines a service performed by government bureaucracy which is carried out in a series of integrated, simple, open, precise, complete, and affordable activities [11].

According to Anisa \& Dewi [12] at the moment, the most popular photo-sharing social media platform for the public is Instagram. The choice of Instagram, as a communication tool, is part of efforts to fulfill the public communication strategy carried out by the Regional Secretariat of the Pangandaran Regency Government with the main target being people who are literate in information through social media, especially prospective local, domestic and foreign tourists. The strengths of social media as suggested by Mulyati in Rachmaniar \& Prasanti [13] that they are popular in the community, creating intense relationships, has a broad and global reach, as well as control and effectiveness that can be measured systematically. With these advantages, social media has become the main communication media for individuals and organizations to greet each other and obtaining various information. Therefore, the advantages possessed by social media need to be considered and explored further by utilizing them in relation to building perceptions, opinions, images, and reputations of individuals and institutions. The implementation of social media utilization is through the selection of communication strategies by following the phenomena experienced by communicators and communicants.

The purpose of the communication strategy is related to the achievement of communication targets on the public side so that they can understand and comprehend the information conveyed by the institution through the communication process itself [14]. From the phenomena obtained in the field, the strategy that can be carried out by the Pangandaran Regency Government in order to communicate messages of policy socialization and work program of government achievements so that it can be conveyed and understood by the public properly. As stated by the Public Relations staff of the Pangandaran regency as well as the @humaspnd account admin, Wildan Syahrizal, he explained that:

"... the dominant content of messages and information posted on Instagram are the activities of the regent, deputy regent, and regional secretary in working as public officials such as visits to offices, attending the inauguration of an event in Pangandaran and outside [the region] and reviewing the implementation of development activities..."

From the statement above, it shows that one of the main tasks of the public relations department of Pangandaran Regency is to convey information about the leadership's activities. The public relations task of the Pangandaran Regency Government is facilitating the Regent, 
and it also accommodates all available data related to governance, which subsequently processes data, analyzes and disseminates it to government agencies under Pangandaran Regency Government. Based on reality obtained in the field, the public relations activities in the Pangandaran Regency Government function as protocols, information, documentation, and as the frontline, especially in the delivery of information about regional heads and government programs for the community. It is a paramount thing to have guidance on how governments should handle the problem and achieving the objectives, including in terms of information services on social media. The guidance is one way to know how the government would understand clearly the implementation of measuring the performance and tasks of public relations in a government institution. People's perceptions can form communication media in the form of mass media, and online as well as Instagram as social media can be a unique attraction Kertamukti [15], including for the Pangandaran community to get information about the activities of their regional leaders. During this time, the messages contained in the @ humaspnd account in the form of photographs and videos that show the situation of the dominant formal and serious leadership activities as part of government communication. Government communication means public communication that touches the elements of community and state interests, communication that occurs between state administrators and their communities to share information, ideas, and attitudes as apparatus and government institutions [16]. The information presented on Instagram generally presents information that is not rigid and somewhat humorous. Because almost all Instagram users are millennials, who want the information to be "light".

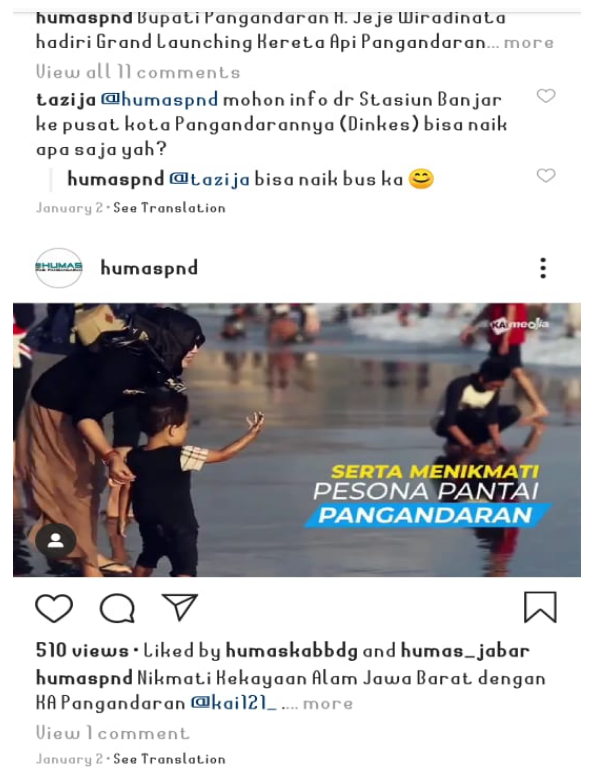

Fig. 2. Message in January 2019 period

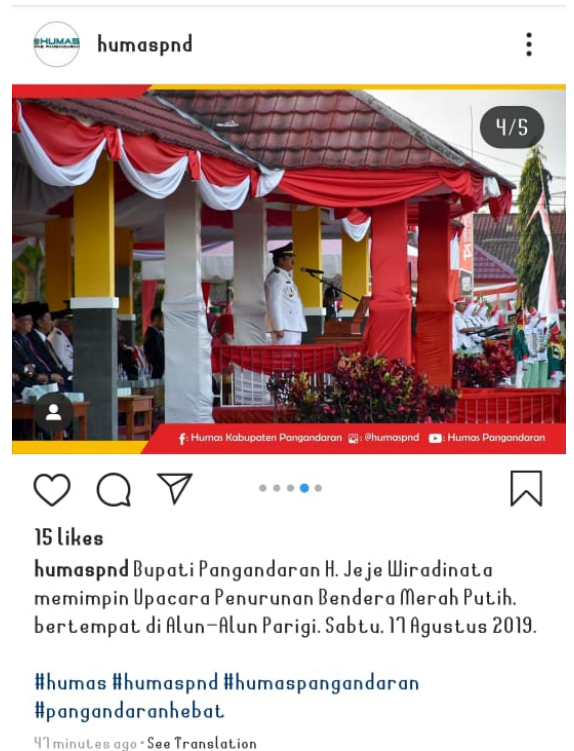

Fig. 3. Message in August 2019 period Sources: @humaspnd Instagram account, 2019.

Figures 2 and 3, show that the information conveyed by the @humaspnd account is still "stuck" in protocol rules; that is, the type of message regarding the activities of regional leaders delivered in a very formal way. While on the other hand, the information presented on Instagram 
is a type of information that relies on the power of visual-centric messages with the addition of persuasive narratives to be shared and known by others enthusiastically as "sharing information through image display" and Instagram stories. In addition to providing information about the activities of regional leaders, the Instagram @ humaspnd presentation also presents videos of regional leadership activities related to some moments of provincial and national activities.

From the results of research conducted, it turns out that the response of the Pangandaran community was more proactive in evaluating the message content contained in the Instagram account@humaspnd compared to the response from the public who saw information from the Pangandaran District government website. The contents of the Pangandaran community's response could from the delivery of the message content on Instagram, which gets a direct answer by the @humaspnd account manager. On the other hand, the number who see every event posted on the @humaspnd Instagram account is always quite high and gets a direct response from followers. Proves that current social media is more effective than conventional media such as television, radio, magazines and newspapers. Thus, the use of Instagram as a medium of communication and information Public Relations of the Pangandaran District government is considered effective in conveying the information on the development and government policies in the form of text, photos and audio-visuals that can attract the attention of the public to engage.

\section{Conclusion}

New media in the form of Instagram have been used and utilized by various organizations, including the Pangandaran Regency Government in order to convey public information to the public. The type of information contained in Instagram @ humaspnd relates to the activities of regional leaders, namely the regent, deputy regent, and regional secretary in their duties as state officials. The information through Instagram provides certainty, a precise, accurate, and trusted public communication strategy in the digital age.

The use of Instagram social media is part of the public communication strategy of the Pangandaran Regency Government in addition to a previously established digital media such as Facebook and website. The choice of using Instagram is related to the more elegant appearance of Instagram presentations in presenting information in the form of limited images or photos and videos that can attract people's attention. So, with the public communication strategy carried out by the Regional Secretariat of Pangandaran Regency, this will be a media liaison of information between the community and institutions and maintaining "relations" between the servants and the served.

\section{References}

[1] D. N. Ayutiani and B. P. S. Putri, "Penggunaan akun instagram sebagai media informasi wisata kuliner," Profesi Humas, vol. 3, no. 1, pp. 39-59, 2018.

[2] A. N. Islami, "Instagram: Media Sosial dan Eksistensi Diri Remaja Berprestasi di Kota Palu," Kinesik, vol. 5, no. 3, pp. 1-15.

[3] A. R. Iik and R. Panuju, "Strategi Komunikasi Pemasaran Produk Fair N Pink Melalui Media Sosial Instagram," J. Wacana, vol. 16, no. 2, pp. 214-224, 2017.

[4] P. Chakravartty and K. Sarikakis, "Media policy and globalization," in Media Policy and Globalization, vol. 1, no. 1, 2006, pp. 1-211.

[5] R. F. Marta, "Polemik Kebhinnekaan Indonesia Pada Informasi Instagram@ Infia_Fact Terkait 
Patung Kwan Sing Tee Koen Tuban,” Bricol. J. Magister Ilmu Komun., vol. 3, no. 02, pp. 63-71, 2018.

[6] G. Gumilar, "Pemanfaatan instagram sebagai sarana promosi oleh pengelola industri kreatif fashion di kota Bandung," JIPSI-Jurnal Ilmu Polit. dan Komun. UNIKOM, vol. 5, no. 2, 2016.

[7] N. Afkarina, "Strategi komunikasi humas dalam membentuk public opinion lembaga pendidikan," J. Idaarah, vol. 2, no. 1, pp. 50-63, 2018.

[8] W. Prihatiningsih, "Motif Penggunaan Media Sosial Instagram di Kalangan Remaja," Communication, vol. 8, no. 1, pp. 51-65, 2017.

[9] R. Nasrullah, "Peer Riview Etnografi Virtual Riset Komunikasi Budaya Sosioteknologi Di Internet (Reviewer 1).” Simbiosa Rekatama Media, 2017.

[10] A. J. Satyadewi, H. Hafiar, and A. R. Nugraha, "Pemilihan Akun Media Sosial Instagram oleh Holiday Inn Bandung," J. Messenger, vol. 9, no. 2, pp. 153-162, 2017.

[11] C. S. Hutasoit, "Pelayanan Publik Teori dan Aplikasi," Jakarta Magna Scr. Publ., 2011.

[12] R. Anisa and R. Dewi, "Kampanye lingkungan Greenpeace pada media sosial instagram," in Strategi Komunikasi Lingkungan dalam Organisasi, 1st ed., I. Bakti, S. Sumartias, H. Agustin, and P. Subekti, Eds. Bandung: Unpad Press, 2019.

[13] Rachmaniar and D. Prasanti, "Keberadaan akun instagram @komunitas1000kebun dan info zero wate," in Strategi Komunikasi Lingkungan dalam Organisasi, 1st ed., I. Bakti, S. Sumartias, H. Agustin, and P. Subekti, Eds. Bandung: Unpad Press, 2019, pp. 78-84.

[14] N. Arumsari, W. E. Septina, M. Luthfi, and N. K. A. Rizki, "Komunikasi Politik Kepala Desa dalam Mendorong Inovasi Pembangunan Desa: Studi Kasus Tiga Desa di Lereng Gunung Ungaran, Jawa Tengah,” Polit. Indones. Indones. Polit. Sci. Rev., vol. 2, no. 1, pp. 86-99, 2017.

[15] R. Kertamukti, "Instagram dan Pembentukan Citra (Studi Kualitatif Komunikasi Visual dalam Pembentukan Personal Karakter Account Instagram@ basukibtp),” Profetik J. Komun., vol. 8, no. $1,2015$.

[16] Y. Z. Abidin, "Komunikasi Pemerintahan, Filosofi, Konsep dan aplikasi," Bandung: Pustaka Setia Bandung, 2016. 